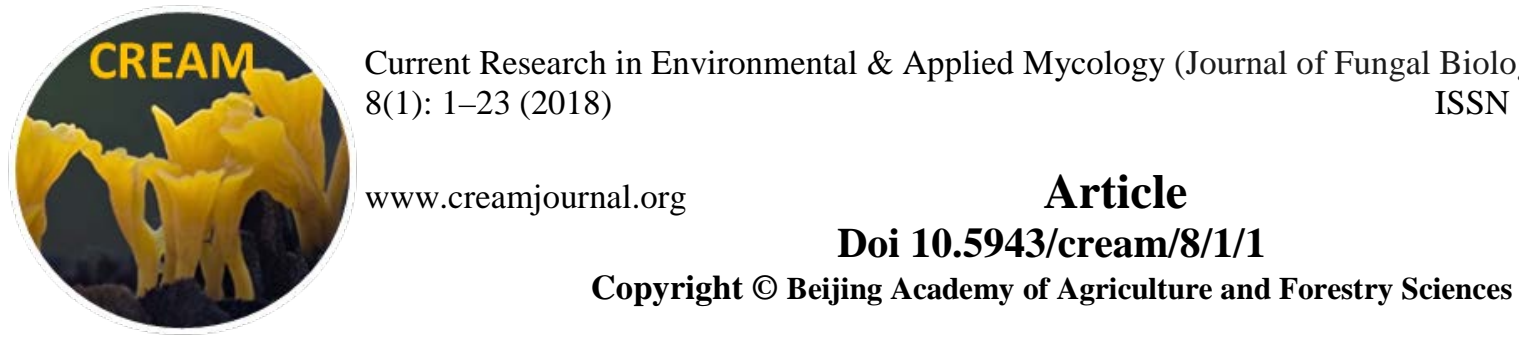

\title{
Healing mushrooms of Uttarakhand Himalaya, India
}

\section{Bhatt RP, Singh U and Uniyal P}

Department of Botany \& Microbiology, H.N.B. Garhwal University (A Central University), Srinagar, Garhwal, 246174, Uttarakhand, India

Bhatt RP, Singh U, Uniyal P 2018 - Healing mushrooms of Uttarakhand Himalaya, India. Current Research in Environmental \& Applied Mycology (Journal of Fungal Biology) 8(1), 1-23, Doi $10.5943 /$ cream/8/1/1

\begin{abstract}
The Himalayan forests of Uttarakhand represent a natural repository for the rich biodiversity of the Indian subcontinent. Forest resources in this region form an integral part of socio-economy and cultural practices. Mushrooms are forest products which have been used as food for a long time but very few for therapeutic purposes, which is associated to the lack of awareness and knowledge. If properly identified, these mystic organisms can be very promising in prevention and cure of various ailments. The present study is a part of macrofungal exploration carried out from 20152016. As a result, 15 mushroom species are identified which possess a spectrum of bioactive compounds and therapeutic potential. All of these species are morphologically described along with the habit, habitat and notes on their healing capacities.
\end{abstract}

Key words - Medicinal mushrooms - Uttarakhand Himalaya

\section{Introduction}

The medicinal properties of mushrooms have been known about for millennia and were exploited for the benefit of humans by many ancient civilizations, including those in Ancient China, Eastern Europe, Mesoamerica and Africa (Wasser 2011). Mushrooms have featured in traditional Chinese medicine for more than 3,000 years of use for the prevention and treatment of diseases and dried extracts from fruit bodies occupy a lucrative segment of the market for herbal medicines in western countries (Chang 2004, Money 2016).

Mushrooms are known to be medically active in several therapies, such as antitumour, antibacterial, antiviral, haematological and immunomodulating treatments (De Silva et al. 2012a, b, 2013, Venkatachalapathi \& Paulsamy 2016). The therapeutic effect is linked to the presence of bioactive compounds in mushrooms. A large variety of secondary metabolites in form of organic acids, alkaloids, terpenoids, polyketides, steroids and phenolic compounds are produced by mushrooms and responsible for various health promoting properties like antioxidant, antiinflammatory and cholesterol lowering effects (Onbaşili et al. 2015, Kosanić et al. 2016). Several species of mushrooms have been reported to markedly inhibit the growth of various tumours (Wasser \& Weis 1999a, Park 2014).

Uttarakhand is one of the hotspots of global biodiversity and is situated in the western part of the central Himalayas. It enjoys one of the most important locations on the political map of India, extending from 28'43” $\mathrm{N}$ to 31'28” $\mathrm{N}$ latitude and 77'34” $\mathrm{E}$ to 81 '03” E longitude. The total geographical area of the region is $53,483 \mathrm{~km}^{2}$ which accounts for nearly 15.5 per cent of the total 
geographical area of the western Himalayas and 1.63 per cent of the total land area of India. The recorded forest area of the state is approximately 34,650 $\mathrm{km}^{2}$ (Botanical Survey of India) accounting for $62.27 \%$ of the area of state (Kumari \& Tiwari 2009, Joshi et al. 2012). Six major forest types described in Uttarakhand are: tropical moist deciduous forest, tropical dry deciduous forest, subtropical pine forest, Himalayan moist temperate forest, Himalayan dry temperate forest and subalpine/alpine forest (Champion \& Seth 1968). The forest cover of the Uttarakhand Himalaya extends over an elevation range of 250 to $3500 \mathrm{~m}$ and most of the forests present are dominated by species of Quercus, Rhododendron, Pinus, Cedrus, Cupressus, Abies, Picea, Shorea and Betula. These forests provide sufficient diversity in vegetation and the favourable environmental conditions to support the growth and development of fleshy macrofungi (Joshi et al. 2012). Present investigation deals with the exploration, identification and documentation of mushrooms with the therapeutic potentials from Uttarakhand.

\section{Materials \& Methods}

Numerous field trips were made to different study sites in the Uttarakhand Himalaya (Fig. 1) between March and November of 2015-2016. Standard methods were followed for the collection, preservation, macro- and microscopic studies of the specimens (Singer 1986). Photographs of all specimens were obtained using a Sony digital DSC-W730 and Cannon Power Shot SX 50 cameras. Identification of species was based on critical observations of the specimens and perusal of the

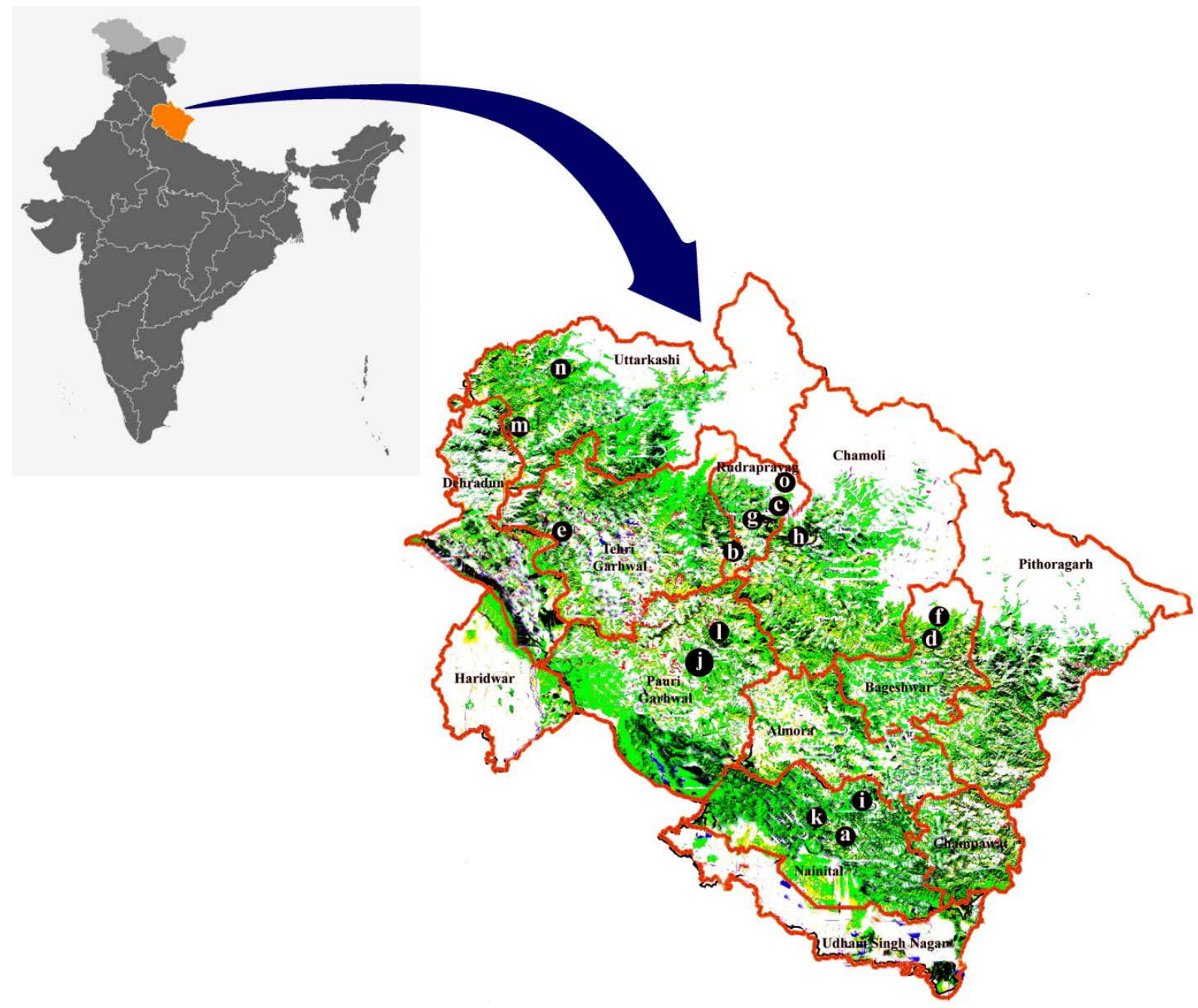

Fig. 1 - Study sites in Uttarakhand. a Bhimtal. b Chirbatiya. c Chopta. d. Dhakuri. e. Dhanaulti. f Dwali. g Kund h Mandal i Mukteshwar. j Nagdev-Jhandidhar. k Nainital. l Phedkhal. m. Purola. n Sankri. o. Tungnath. 
relevant literature (Moller 1950, 1952, Moser 1978, Hesler \& Smith 1979, Miller 1981, Arora 1986, Singer 1986, Kibby \& Fatto 1990, Phillips 1991, Heilmann-Clausen et al. 1998, Das \& Sharma 2005). The colour terminology used is that of the Methuen Handbook of Colour (Kornerup \& Wanscher 1978).

\section{Results \& Discussion}

Fifteen species belonging to 15 genera and 14 families of wild medicinal mushrooms were recorded. Of the species collected, Cordyceps militarius, Ophiocordyceps sinensis and Morchella esculenta are the members of Ascomycota and rest mushrooms considered herein are Basidiomycota. A brief description of all the species is given below along with their habit, habitat and medicinal properties.

\section{Agaricaceae}

Agaricus campestris L. [as 'campester'], Species Plantarum 2: 1173 (1753)

Fig. 21

Pileus 30-80 $\mathrm{mm}$ broad, hemispherical, then convex later expanded to plane or with slightly uplifted margin at maturity, pure white or yellowish white (2A2) when young, discolouring yellowish with age, surface dry, smooth, finely fibrous or sometimes with minute, white to light grey (1C1) to medium grey (1E1) scales at centre; margin entire, decurved, occasionally upturned at maturity, hung with appendiculate to pendant veil remmants; context up to $8 \mathrm{~mm}$ thick at disc, thinning towards margin, white, unchanging on exposure and with $\mathrm{KOH}$. Lamellae free at maturity, close, with 3-5 series of lamellulae, pinkish white (8A2) when young, becoming dull red (10C4) finally chocolate brown or dark brown (6F4, 7F8). Stipe 36-85 $\times 5-12 \mathrm{~mm}$, centric, equal or slightly attenuated at base, white, surface glabrous, often appressed fibrillose, stuffed or hollow; context white, unchanging on exposure. Annulus superior, white, thin, skirt like. Taste mild. Odour fungal. Spore deposit dark brown (7F8).

Habit and habitat - Solitary to scattered, associated with grasses, especially with Cyanodon, commonly found along road side and meadows.

Specimens examined - India: Uttarakhand, Rudraprayag, Chirbatiya, RPB/US/PU-0931, 12 August 2015; Chopta-Baniyakund, RPB/US/PU 0942, 16 August 2015.

Medicinal properties - Agaricus campestris is a common meadow mushroom which matures fast and has a short shelf life. A. campestris is used for the treatment of ulcers and bed sores. It has been a folk remedy for burns in Scotland. Lectins isolated from the solvent extract of this fungus are assumed to be responsible for anti-diabetic activity by enhancing insulin release (Gray \& Flatt 1998, Waheed et al. 2013). Administration of A. campestris is effective in reducing hyperglycemia in STZ diabetic mice by protecting B-cells against the cytotoxic action of streptozotocin (STZ) (Gray \& Flatt 1998).

\section{Auriculariaceae}

Auricularia auricula-judae (Bull.) Quél., Enchir. fung. (Paris): 207 (1886)

Fig. 10

Pileus 20-110 mm broad, ear-shaped to irregularly lobed, tough-gelatinous, semi-transparent, sessile or sub-stipitate; outer surface tan-brownish orange (5C6), covered with fine greyish velvety hairs; margin entire at first, becoming somewhat lobed with age; context thin (up to $15 \mathrm{~mm}$ ), gelatinous or cartilaginous, becoming hard on drying. Hymenium pale orange (5A3), veined, irregular often. Taste and Odour indistinct. Spore deposit not found.

Habit and habitat - growing in clusters on dead or decaying hardwood and conifer logs.

Specimens examined - India: Uttarakhand, Rudraprayag, Tungnath trek, RPB/US/PU-0858, 05 August 2015; Uttarkashi, Sankari, RPB/US/PU-0894, 08 August 2015.

Medicinal properties - Auricularia auricula-judae has been used traditionally as medicine in many countries for anti-diabetic, antitumor, antihypertensive, anti-inflammatory, 
immunomodulatory and anti-bacterial properties. Water soluble polysaccharides of A. auriculajudae cause the hypoglycemic effect in genetically diabetic mice to result in reduced fasting plasma
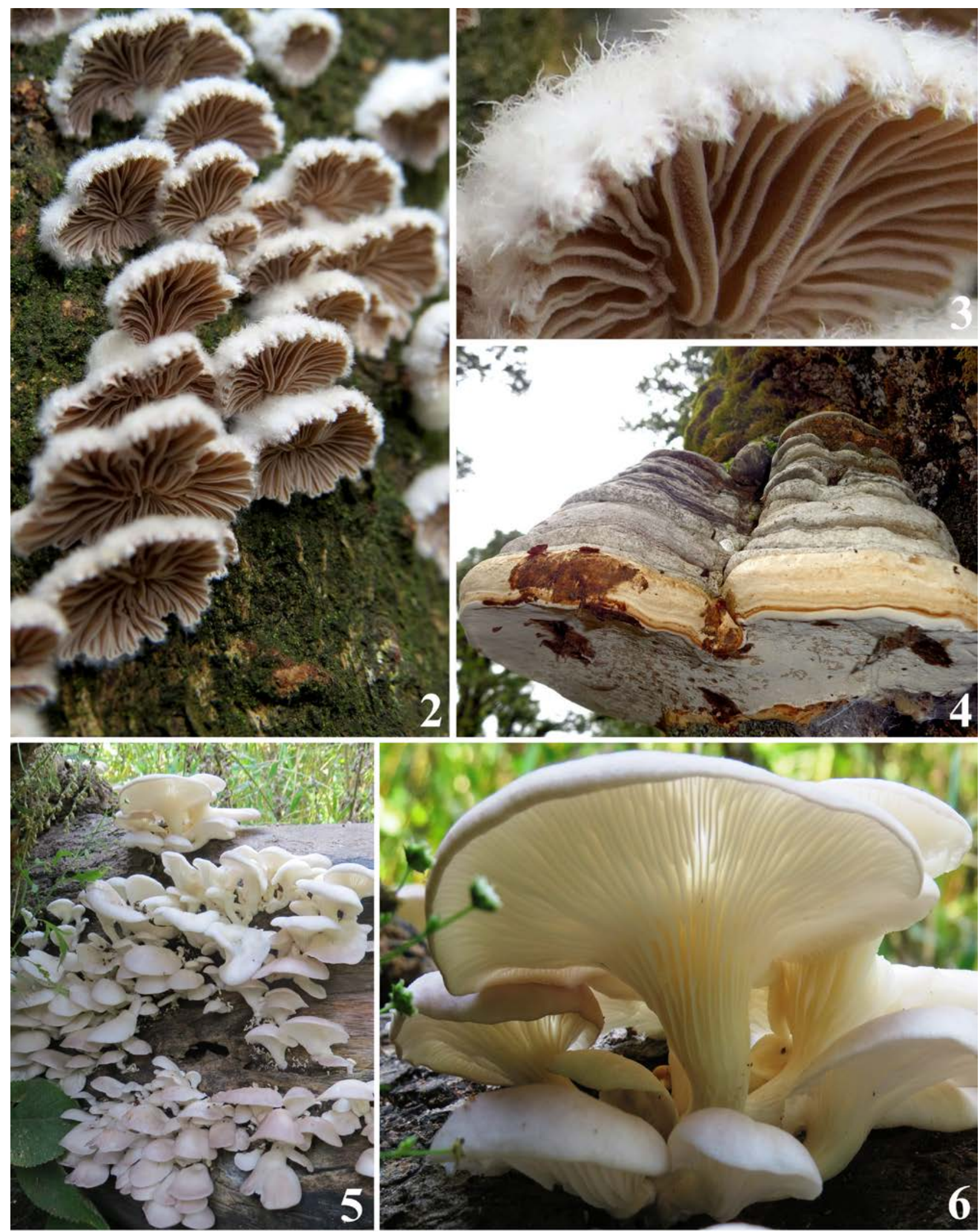

Figs 2-6 - 2 Schizophyllum communae on trunk of Celtis australis. 3 Split gills and wooly pileus surface of $S$. commune. 4 Fomes fomentarius. 5 Pleurotus ostreatus growing in clusters on dead log. 6 P. ostreatus. 
glucose concentration and improve the glucose tolerance (Gurusamy \& Arthe 2012, Yuan et al. 1998).

Glucuronoxylomannans (MEA and MHA) are the acidic heteroploysaccharides present in this mushroom which show antitumor activities (Ukai et al. 1983). Polysaccharides of A. auricula-judae are effective against EAC (Ehrlich ascites carcinoma) in induced mice (Gurusamy \& Arthe 2012). Studies suggested that antitumor efficiency of $70 \% \mathrm{EtOH}$ extract is more than water extract of $A$. auricula-judae and also in comparison of organic plant extracts (Reza et al. 2012). Wound healing capacity of polysaccharides of A. auricula-judae was demonstrated by Khamule et al. (2012), where a healing effect was expressed as normalized epidermal migration and a significant wound healing was observed at $100 \mu \mathrm{g}$ per wound.

Acidic polysaccharides isolated from A. auricula-judae also show anticoagulant activity by enhancing the catalysis of thrombin inhibition by antithrombin and inhibition of platelet aggregation (Yoon et al. 2003).

\section{Boletaceae}

Boletus edulis Bull., Herb. de la Fr. 2: t. 60 (1782)

Fig. 23

Pileus 45-87 mm broad, hemispherical to convex when young, broadly convex with age, golden yellow (5B7), yellowish brown (5E6) to cinnamon brown (6D6) or dark brown (6F7), dusted with a whitish bloom, surface dry, glabrous, smooth, shallowly wrinkled; margin regular, smooth, incurved when young, yellowish white (2A2); context firm when young, spongy with age, 12-22 mm thick at disc, white, unchanging on exposure or bruising. Tubes $10-17 \mathrm{~mm}$ deep, adnexed but depressed around the stipe, white to yellowish white (2A2) when young, olive yellow (2C6) with age, unchanging on bruising. Pores minute, 2-3 per $\mathrm{mm}$, angular to irregular, concolorous with tubes, unchanging when bruised. Stipe 45-100 × 30-75 mm, central, clavate to broadly clavate, whitish to light brown (5D7) at apex, brown (6D8) in middle, yellowish white (2A2) at base, covered with a white reticulum, usually from apex to middle. Taste mealy. Odour pleasant. Spore deposit olive brown (4E5).

Habit and habitat - Solitary, scattered to gregarious, under Quercus semecarpifolia.

Specimens examined - India, Uttarakhand, Rudraprayag, Chopta-Baniyakund, RPB/US/PU0616, 14 July 2015; Chamoli, Mandal, RPB/US/PU-0654, 16 July 2015.

Medicinal properties - Boletus edulis is also known as the King bolete, Penny bun, Porcino or cep and highly valued worldwide for culinary purposes. Biopolymers of $B$. edulis like polysaccharides and glycoproteins act as anticancer agents. Polysaccharides of this mushroom are known to reduce colon carcinoma cell proliferation by arresting the cell cycle in G0/G1 phase. Polysaccharides of $B$. edulis also have anti-inflammatory capacities and can reduce asthma severity by improving airway resistance (Wu et al. 2016).

An anticancer effect is shown by $B$. edulis lectins (BEL) which exerts strong antiproliferative activity toward human carcinoma cell lines (Bovi et al. 2011, Lemieszek et al. 2013). BEL also have stimulating effect on mitogenic response of mouse splenocytes and able to inhibit HIV-1 reverse transcriptase enzyme in vitro (Bovi et al. 2011, 2013, Zheng et al. 2007).

\section{Cordycipitaceae}

Cordyceps militaris (L.) Fr., Observ. mycol. (Havniae) 2: 317 (cancellans) (1818) $\quad$ Figs 14 \&15 Fruitbody $20-55 \times 2-5 \mathrm{~mm}$, club-shaped; upper portion fertile, granular, covered with raised pores, persian orange to deep orange (6A7-6A8); context concolorous; lower portion sterile, smooth, often curved or somewhat wavy, light orange (5A5), tapering at the base attached to a dead insect pupa or larva under the soil. Taste and odour indistinct. Spore deposit not found.

Habit and habitat - Solitary to gregarious, growing on dead insect pupa or larva.

Specimen examined - India, Uttarakhand, Rudraprayag, Chopta-Baniyakund, RPB/US/PU0635, 15 July 2015. 

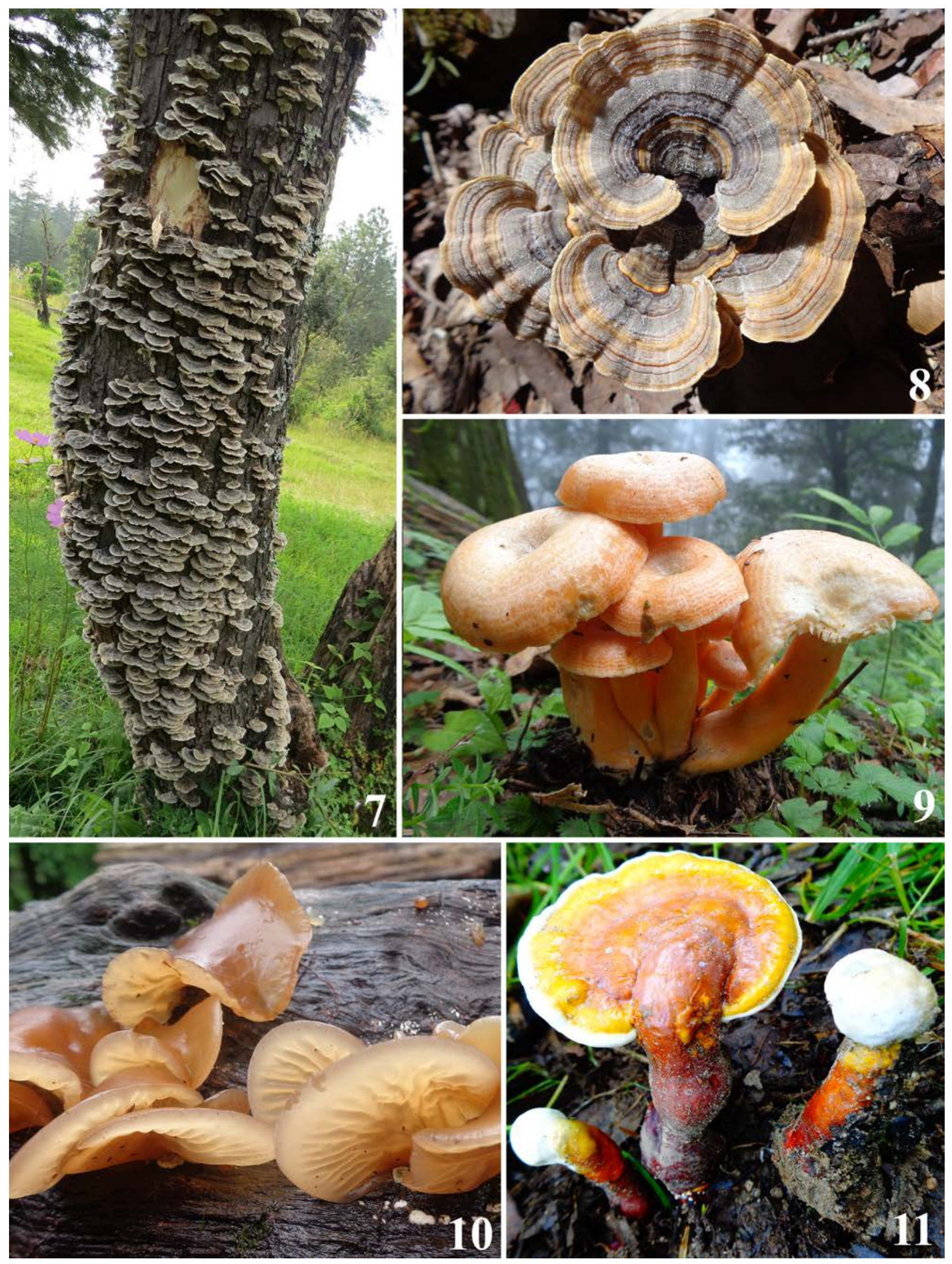

Figs 7-11 - 7 Trametes versicolor on stem of Pyrus pashia. 8 Coloured zonations in T. versicolor. 9 Lactarius deliciosus. 10 Auricularia auricula-judae. 11 Ganoderma lucidum.

Medicinal properties - Cordyceps militaris is one of the most valuable medicinal mushrooms and neutraceuticals in China (Zhang et al. 2016). It is an asexual morph of 
Ophiocordyceps sinensis commonly used as a substitute of the natural Cordyceps (Li et al. 2006). It possesses many kinds of active components (such as cordycepin, polysaccharides, ergosterol, and mannitol), and due to its several physiological activities, it is currently used for multiple medicinal purposes (Patel \& Ingalhalli 2013).

Therapeutic potential of this fungus is mostly derived from a protein, Cordycepin (3'deoxyadenosine) which exhibits antioxidant, antimicrobial, anticancer, antimetastatic, immunomodulatory and insecticidal effects and also effective on cerebral ischemia (Patel \& Ingalhalli 2013, Wang et al. 2012). Supplementation of C. militaris also helps in increasing sperm number, percentage of motile sperm cells, in curing cough and sputum, abnormal respiratory functions, myodesopsia and diabetes (Mizuno 1999).

Polysaccharides of $C$. militaris show hypoglycemic effects and its water extracts possess notable activity via increment of insulin secretion and cholinergic activation. Glucose metabolism is enhanced by alleviating hepatic glucokinase, hexokinase and glucose-6-phosphate dehydrogenase activities (Dong et al. 2014). Water extract of $C$. militaris may inhibit tumor cell proliferation via arresting the cell cycle at the G2/M phase and induce apoptosis through upregulation of p53, p21, and cyclin B1, as well as the activation of caspase-8, caspase-9, and caspase-3 (Yang et al. 2012).

\section{Ophiocordycipitaceae}

Ophiocordyceps sinensis (Berk.) G.H. Sung, J.M. Sung, Hywel-Jones \& Spatafora, Studies in Mycology 57: 46 (2007)

Figs 19 \& 20

Fruitbody 30-75 × 2-4 mm, yellow when young, dark brown (6F7) to black with age, upper part fertile, granular, clavate, sublanceolate or fusiformis; lower part sterile, cylindrical, glabrous, longitudinally ridges or furrows, attached to a dead insect larva below the soil. Taste and odour indistinct. Spore deposit not found.

Habit and habitat - Solitary to scattered, growing on dead insect larva.

Specimen examined - India, Uttarakhand, Bageshwar, Dhakuri, RPB/US/PU-1036, 11 June 2016.

Medicinal properties - Ophiocordyceps sinensis is used as a traditional medicine since ancient times due to its incredible medicinal properties (Seth et al. 2014). It is commonly called as "Keera ghas" or "Keera jadi” in India, "Yartsa gunbu" in Tibet, "Dong Chung Ha Cao" in Korea, "Tochukasu" in Japan and "Dong Chong Xia Cao" in China. It is believed that Ophiocordyceps was discovered about 1500 years ago in Tibet by herdsmen who observed that their livestock became energetic after eating it growing locally (Arora 2015). Due to its potential medicinal value, $O$. sinensis has a huge market and is highly priced. Its collection therefore has become a good source of income for the locals in Indian Himalayan region. In rural Tibet it has become the most important source of cash income (Bhandari et al. 2012, Paliwal et al. 2015).

Adenosines, Amino acids, Cyclofurans, Polysaccharides, Ergosterol, Cordyglucans, Cordycepic acid and Cordycepin are the main constituents which are responsible for the therapeutic potential of $O$. sinensis. Antitumor, anti- HIV (by suppression of viral replication and inhibition of RNA/DNA synthesis), anti malarial and anti-leukemia activities are due to the presence of cordycepin (Arora 2015, Trigg et al. 1971, Kuo et al. 1994, Miller 2005, Ng \& Wang 2005, Kharkwal 2016).

Use of natural Ophiocordyceps to ameliorate conditions associated with ageing and senescence is centuries old. The antisenescence effects of Ophiocordyceps are due to activation of SOD (Superoxide Dismutase) to scavenge oxygen free radicals (Zhu et al. 1998). It is a potent medicine for curing hypolibidinism, impotence and also used as an adjunct to chemotherapy in cancer treatment. $O$. sinensis is used in treatment of bronchitis, asthma, chronic obstructive pulmonary disease (COPD) and various renal problems like mesangial neuropathy and nephrotoxicity (Seth et al. 2014, Arora 2015). 

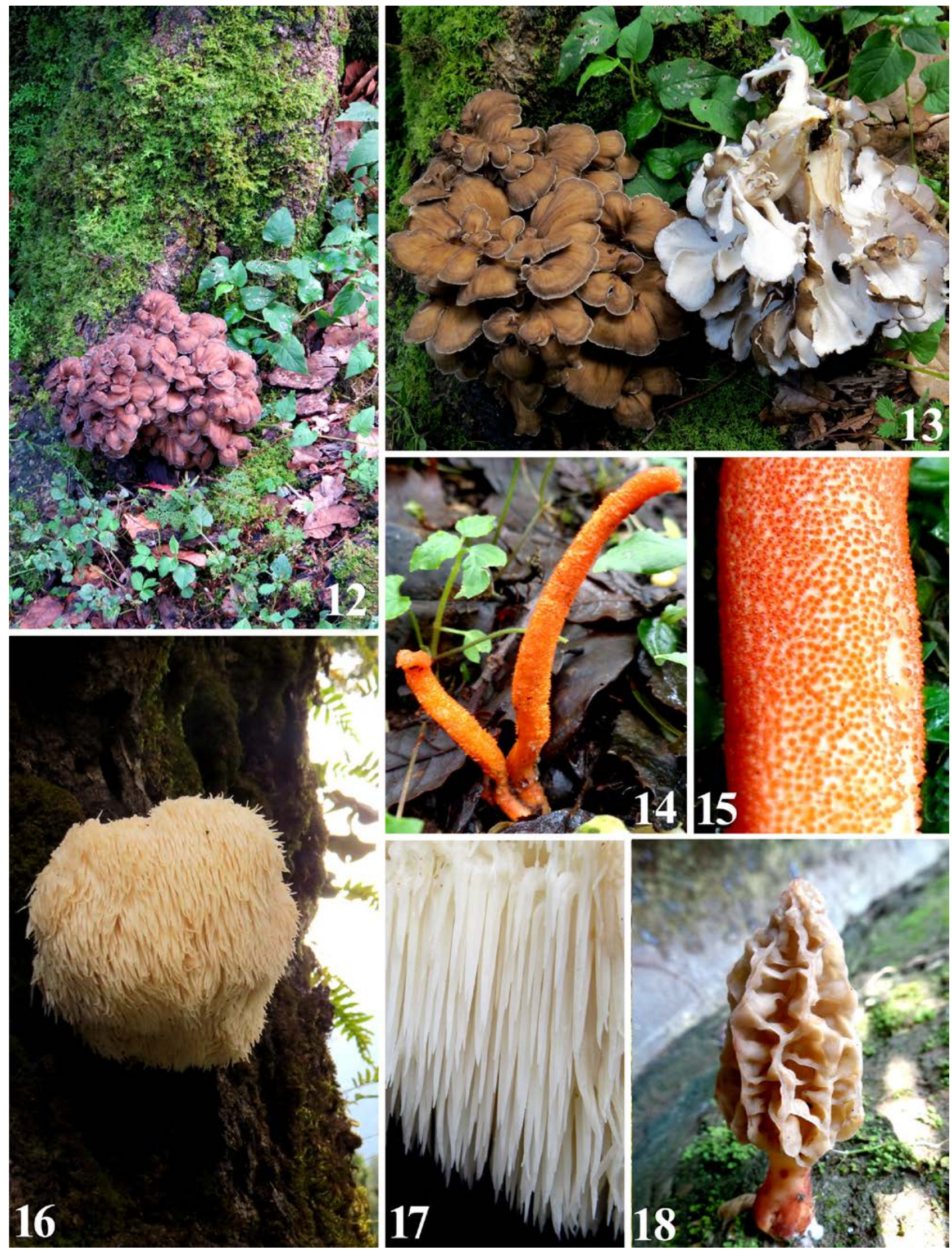

Figs 12-18 - 12 Basidiome of Grifola frondosa at the base of Quercus semecarpifolia. 13 Dorsal and ventral view of $G$. frondosa. 14 Cordyceps militaris. 15 Granular surface (raised pores) of $C$. militaris. 16 Hericium erinaceus on $Q$. semecarpifolia. 17 Fertile hanging spines of $H$. erinaceus, 18 Morchella esculenta. 
Immunosuppressive and immune-stimulating effects are shown by various extracts of $O$. sinensis. Mycelia and fruiting bodies of $O$. sinensis are rich in adenosine and therefore cause mild hypotensive effect and inhibition of platelet aggregation. It shows anti arrhythmic, vasodilating effect and enhanced erythropoiesis (Chakraborty et al. 2014).

Ophiocordyceps is a remedy for weakness and fatigue and is often used as an overall rejuvenator for increased energy while recovering from serious illness. It increases cellular ATP and makes the utilization of oxygen more efficient (Holliday \& Cleaver 2004, Seth et al. 2014).

Polysaccharide fraction of $O$. sinensis shows the anti-diabetic effects by lowering the blood glucose level. Among the multiple polysaccharides produced by Ophiocordyceps, beta-d-glucans are one class of these polymers that have been shown to increase both innate and cell-mediated immune response. These polysaccharides increase the production of such cytokines as TNF-a, interleukins, and interferons, NO, and antibodies by the activated immune cells (Holliday \& Cleaver 2004).

\section{Ganodermataceae}

Ganoderma lucidum (Curtis) P. Karst., Revue mycol., Toulouse 3(9): 17 (1881)

Fig. 11

Pileus 25-120 mm broad, elongated when young, more or less fan-shaped with maturity, surface smooth, glossy, shiny, concentrically sulcate, yellowish brown (5E8) to reddish brown (8E8); margin obtuse, white; context white. Tubes whitish to brown, up to $10 \mathrm{~mm}$ deep; pore surface white to yellowish white (3A2), light brown to brown (7D5-7D7) when bruised or on maturity, pore rounded to ovate, 5-7 per mm. Stipe $35-110 \times 10-25 \mathrm{~mm}$, central to eccentric, subcylindrical, concolorous with pileus to purplish brown. Taste and odour indistinct. Spore deposit brown (7D7).

Habit and habitat - Solitary to scattered, found to grow at the base of living and dead wood of Quercus spp.

Specimens examined - India, Uttarakhand, Rudraprayag, Chopta-Baniyakund, RPB/US/PU0945, 16 August 2015, Pauri Garhwal, Phedkhal, RPB/US/PU-1395, 24 September 2016.

Medicinal properties - The fungi Ganoderma lucidum (GL) has been used for centuries in East Asia. Its fruiting body is called as 'Reishi' in Japan and 'Lingzhi' in China. It has also been commonly referred to as the "mushroom of immortality", "ten-thousand-year mushroom", "mushroom of spiritual potency" and "spirit plant”. It was listed among the superior tonics [Shang pin] in the most famous of all Chinese material medicas, the Shen Nung Ben Cao Jing (206 BC-AD 8). In these areas, GL has been a popular folk or oriental medicine to cure various human diseases such as hepatitis, hypertension, hypercholesterolemia, gastric cancer (Wasser \& Weis 1999b, Yun 1999, Nahata 2013) and lung cancer (Tang et al. 2006). G. lucidum has been used for its analgesic and muscle relaxing properties since ancient times (Zhang et al. 2011). This fungus has been predominantly used by Asian populations to not only improve wellbeing and general health (Shiao 2003), but has also been used alone or alongside western chemotherapy treatment to inhibit cancer or to assist with side-effects (Gordan et al. 2011, Papadopoulos et al. 2007, Sliva 2003). It also acts as a promising herbal medicine for treatment of overactive bladder (OAB) (Ngestiningsih et al. 2013).

Polysaccharides extracted from G. lucidum have also been found to improve anti-tumour immune response by promoting the activity of natural killer cells and cytotoxic T-lymphocytes (Chang 2004, Pan et al. 2013). In addition, the polysaccharides from this fungus are shown to enhance expression of major histocompatibility complex in a melanoma cell line, which improves antigen presentation thus promoting viral and cancer immunity (Sun et al. 2011).Various types of extracts from $G$. lucidum have shown carcinostatic effects in a wide variety of cancer cell lines, including breast, pancreas, lung, colon, skin, and prostate (Wachtel-Galor et al. 2011). There are many mechanisms by which the G. lucidum extracts exhibit anti-cancer activities. These include direct inhibition of cell proliferation through cancer-specific cell cycle arrest and apoptosis (Bishop et al. 2015). 
Triterpenoids of G. lucidum have anti-HIV-1 protease activity (Min et al. 1998). G. lucidum also contains laccases which may inhibit HIV-1 reverse transcriptase (Wang \& Ng 2006). It also exerts inhibitory effects on the proliferation and migration of prostate cancer cells which is due to its ability to inhibit $5 \alpha$-reductase which converts testosterone to dihydrotestosterone (Jian et al. 2004, Liu et al. 2007).

\section{Hericiaceae}

Hericium erinaceus (Bull.) Pers., Commentatio de Fungis Clavaeformibus: 27 (1797)

Figs $16 \& 17$

Basidiomata 56-96 × 42-69 mm, white to yellowish white (2A2), stipitate. Primary branches arising from a base rooting into the dead wood. Primary branches wide up to $11 \mathrm{~mm}$, yellowish white (2A2) in colour, has small spines (up to $3 \mathrm{~mm}$ long) all around, giving rise to secondary branches. Secondary branches comparatively thinner (up to $8 \mathrm{~mm}$ ), has no spines and bearing tertiary branches. Tertiary branches are fertile, wide up to $4 \mathrm{~mm}$ and bear spines. Spines dense, tapering, pendant, white, up to $28 \mathrm{~mm}$ long. Context yellowish white (2A2), unchanging with FeSO4, turning lemon yellow with $\mathrm{KOH}$ and dark orange with Guaiacol. Taste and Odour pleasant. Spore deposit white to yellowish white (2A2).

Habit and habitat - Solitary, growing on dead wood of Quercus spp. in moist temperate mixed forest.

Specimens examined - India, Uttarakhand, Rudraprayag, RPB/US/PU-0952, 16 August 2015, Bageshwar, Dwali, RPB/US/PU-1019, 31 August 2015, Dhakuri, RPB/US/PU-1264, 02 August 2016.

Medicinal properties - Hericium erinaceus, commonly known as Lion's mane or Pom pom blanc, "Houtou" in China and "Yamabushitake" in Japan is highly prized for its medicinal values which are due to several bioactive metabolites and have been a traditional mushroom in Eastern Asia since ancient times. Medicinal properties of $H$. erinaceus are mostly due to its therapeutic polysaccharide contents which are composed of $\beta$-glucans (Ying et al. 1987, Thongbai et al. 2015).

Han et al. (2013) reported a significant antioxidant activity of its polysaccharides against ischemia reperfusion induced renal oxidative injury. It is also found useful in treatment of dementia, cognitive dysfunction and cardiovascular complications (Mori et al. 2011). $\beta$-glucans extracted from submerged mycelia culture of $H$. erinaceus show significant anticancer properties in animal systems (Thongbai et al. 2015). Inhibition of the growth of various bacteria, like Bacillus cereus, B. subtilis, Enterococcus faecalis, Salmonella sp., Shigella sp. and Plesiomonas shigelloides is reported by Wong et al. (2009). Hericium erinaceus polysaccharides are capable of increasing tissue glycogen content, antioxidant enzyme activity and decreasing the contents related to fatigue, including blood lactic acid, serum urea nitrogen and malondialdehyde. (Wong et al. 2009, He et al. 2017).

Immuno-regulatory functions of $H$. erinaceus have been demonstrated in an aqueous extract by a stimulation of inducible nitric oxide gene expression followed by nitric oxide production in macrophages via enhancement of activation of the transcription factor, NF-kappaB (Son et al. 2006). Exo-polymers produced in submerged mycelia culture show a potent hypolipidemic effect (Yang et al. 2003, Yang et al. 2002). Ethanol extract of H. erinaceus is capable of inhibiting platelet aggregation induced by collagen (Mori et al. 2010).

Hericinones and erinacines extracted from $H$. erinaceus can induce synthesis of Nerve Growth Factors and can be promising to cure neuro-degenerative diseases like Alzheimer. A double-blind placebo-controlled clinical trial showed signs of improvement in subject with cognitive impairment after consumption (Lai et al. 2013, Mori et al. 2009). Dilinoleoylphosphatidylethanolamine (DLPE), isolated from $H$. erinaceus reduces ER stress, which leads to the development of neuro-degeneration and amyloid- $\beta$ peptide $(A-\beta)$ toxicity by decreasing neuronal cell death of neuro-2a cells via the protein kinase $C$ pathway (Nagai et al. 2006, Thongbai et al. 2015). 


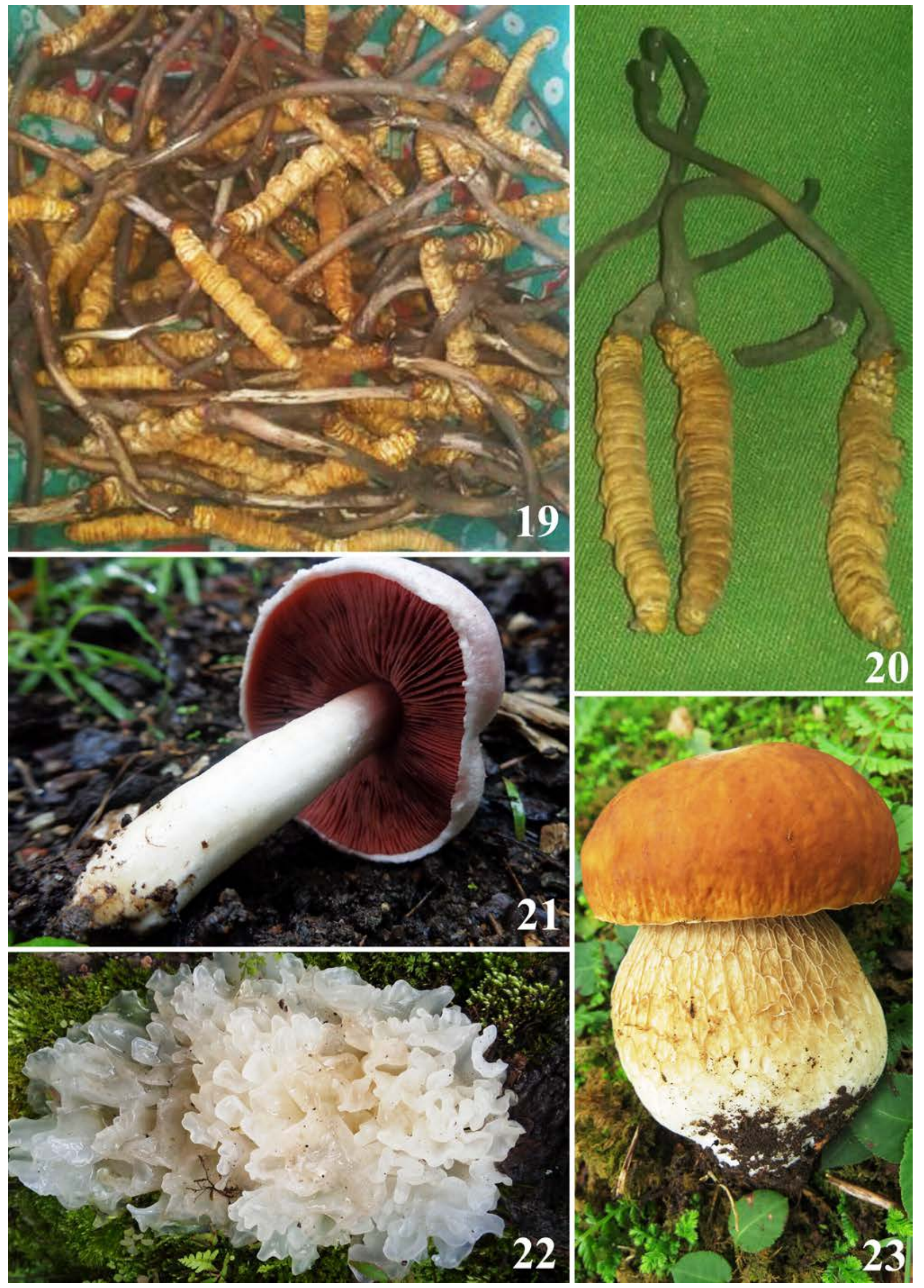

Figs 19-23 - 19, 20 Ophiocordyceps sinensis. 21 Agaricus campestris. 22 Tremella fuciformis. 23 Boletus edulis. 


\section{Meripilaceae}

Grifola frondosa (Dicks.) Gray, Nat. Arr. Brit. Pl. (London) 1: 643 (1821)

Figs $12 \& 13$

Basidiomata 185-345 × 130-215 mm in size, stipitate, multipileate. Pileus $12-80 \mathrm{~mm}$ broad, imbricate, flabelliform, undulating fronds, surface dry, glabrous to finely tomentose, azonate to faintly zonate, smooth or radiately rugose, light brown to yellowish brown (5D5-5D8), dark brown (6D7-8) with age; context yellowish white (2A2), thin, up to $8 \mathrm{~mm}$; margin thin, undulate or curled, white. Hymenophore deccurent, with angular pores, 2-4 per mm, sometimes irregular but never lacerate, white to yellowish-white (2A2), unchanging with $\mathrm{FeSO}_{4}$, Guaiacol, $\mathrm{KOH}$; tubes up to $4 \mathrm{~mm}$ deep, concolorous to pore surface. Stipe $60-100 \times 15-25 \mathrm{~mm}$, branched from a thick base rooting into wood, yellowish white (2A2), white at the base; context yellowish white (2A2), flexible, unchanging with $\mathrm{FeSO}_{4}$, Guaiacol and $\mathrm{KOH}$. Taste mild, pleasant. Odour pleasant, mushroom-like. Spore deposit yellowish white (2A2).

Habit and habitat - Found growing on dead or living stem of Quercus spp. in mixed temperate forest.

Specimens examined - India, Uttarakhand, Rudraprayag, Chopta-Baniyakund, RPB/US/PU0636, 15 July 2015, Uttarakashi, Sankari, RPB/US/PU-0895, 09 August 2015, Bageshwar, Dhakuri, RPB/US/PU-1233, 01 August 2016.

Medicinal properties - Grifola frondosa (Maitake) is also called the king of mushrooms and the hen of the woods (Stamets 1993). Maitake fractions in particular seem to have a specific antitumor action, potentially slowing the growth of tumours in the colon, lungs, stomach, liver, prostate, brain, and other organs. Among various fractions extracted from Maitake, D-fraction is the most potent in enhancing the immune system, demonstrating the highest cancer inhibition in oral administration. It also have ability to potentiate the cellular immune system. Purification of Dfraction results in MD-fraction, which exerts more immunopotentiating activity and stronger inhibitory effect on tumor growth. However, maitake fractions do not destroy the cancer cells but play a role as a potential adjuvant to the chemotherapy. In addition to its antitumor effect, antihypertension, anti-diabetes, anti-obesity and anti-hepatitis activities have been found in Maitake. Its anti-HIV activity was also confirmed by both Japan National Institute of Health and U.S. National Cancer Institute in early 1992. Maitake D-fraction liquid extract mixed with DMSO (dimethylsulfoxide) applied topically is promising as a treatment for Kaposi's sarcoma (Nanba 1997, Mayell 2001).

Numerous studies have confirmed that maitake has prominent beneficial effects on immune function. It promotes the action of not only macrophages, but also a variety of other immunerelated cells, such as natural killer (NK) cells and cytotoxic T-cells (Tc) that can attack tumor cells. Maitake also increases the immune-related efficiency of these cells by increasing interleukin-1, interleukin-2, and lymphokines. The end result is an increased defense against infections, AIDS, and cancer (Mayell 2001).

\section{Morchellaceae}

Morchella esculenta (L.) Pers., Syn. meth. fung. (Göttingen) 2: 618 (1801)

Fig. 18

Pileus 35-80 × 20-45 mm, ovate, apex obtuse, often globular, yellowish white (3A2) to yellowish brown (5D8), pitted; pits up to $15 \times 10 \mathrm{~mm}$, irregular to rounded, up to $7 \mathrm{~mm}$ deep, yellowish within, becoming brown to blackish on drying; ribs usually irregular rather than longitudinally disposed, anastomosing; edges obtuse, up to $2 \mathrm{~mm}$ thick, concolorous with the interior of pits. Stipe $20-80 \times 10-20 \mathrm{~mm}$, cylindrical, sometimes slightly swollen at the base, whitish to yellowish, , hollow, irregularly lacunose at the base but nearly even above, pubescent. Taste pleasant. Odour indistinct. Spore deposit pale yellow (4A3).

Habit and habitat - Solitary to widely scattered, gregarious or clustered, under conifers.

Specimens examined - India, Uttarakhand, Pauri Garhwal, Nagdev-Jhandidhar, RPB/US/PU0601, 31 March 2015; RPB/US/PU-0603, 31 March 2015. 
Medicinal properties - Morchella esculenta is commonly known as morel, common morel, true morel, yellow morel and sponge morel (Prasad et al. 2002). Since commercial cultivation of morels for the fruiting bodies has not been successful till now, the cultured mycelium is extensively used as a flavouring agent. Proteins from the mycelia of Morchella are comparable to vegetative protein and can be used as a good source of protein supplement (Nitha et al. 2007). M. esculenta is cherished for both nutritional and medicinal values because of the possession of many bioactive substances, including polysaccharides, proteins, trace elements, dietary fibers and vitamins. $M$. esculenta has been proven to have anti-inflammatory and antitumor activities, which are attributed to the presence of polysaccharides (Liu et al. 2016). Polysaccharide isolated from the fruiting bodies of $M$. esculenta has been reported to exhibit immunostimulatory activity (Duncan et al. 2001). Extracts of this morel show antibacterial activity against Staphylococcus aureus, Salmonella typhimurium, Listeria monocytogenes, Escherichia coli and Enterobacter cloacae (Heleno et al. 2013).

Mycelia of Morchella esculenta possess beta-carotene and linoleic acid which exhibit antioxidant activities (Mau et al. 2004). The ethanolic extract of its mycelium is also found to possess significant antitumour activity against both ascites and solid tumour (Nitha et al. 2007).

\section{Pleurotaceae}

Pleurotus ostreatus (Jacq.) P. Kumm., Der Führer in die Pilzkunde: 105 (1871)

Figs 5 \& 6

Pileus 45-140 mm broad, fan-shaped, convex to sometimes plane at maturity, white to grey or light greyish brown (5E3), smooth; margin lobed to wavy. Context white, firm. Lamellae decurrent, close, white, pale yellow (2A3) at maturity. Stipe 10-25 $\times 5-15 \mathrm{~mm}$, eccentric-lateral, short, surface smooth, white hairs near the base. Taste mild. Odour anise. Spore deposit white or grey.

Habit and habitat - Growing in shelf-like clusters on dead logs or living trees of hardwoods.

Specimens examined - India, Uttarakhand, Chamoli, Mandal, RPB/US/PU-0653, 16 July 2015; Tehri, Dhanaulti, RPB/US/PU-0756, 31 July 2015; Nainital, RPB/US/PU-1415, 27 September 2016.

Medicinal properties - Pleurotus ostreatus, an edible fungus, is a traditional Chinese medicine which is famous for its delicious taste and high quantities of proteins, carbohydrates, minerals, and vitamins as well as low fat. Its main constituents include polysaccharides, lectin, polypeptide, amino acids, and phenol oxidase. Beneficial effects of $P$. ostreatus include antitumor, antioxidant, blood fat reducing, antiviral, anti-inflammatory, antibiotic, and immunoregulatory properties (Sun \& Liu 2009). Ethanolic extracts of $P$. ostreatus show good DPPH scavenging which reflects its antioxidant properties. It is also antimicrobial and can inhibit Klebsiella pneumoniae, Salmolnella typhii, Staphylococcus aureus, Proteus mirabilis, Escherichia coli, Pseudomonas aeruginosa and Bacillus subtilis (Oyetayo \& Ariyo 2013).

$\beta$-glucan (pleuran), a group of immunomodulating substances called PAMP (pathogen associated molecular patterns) is contained in the cell walls of oyster mushrooms. These molecules are non-specifically identified by the components of the immune system as the structures against which the immune response must be activated. The effect of $\beta$-glucan is realized through a direct contact with immunocompetent cells, macrophages. So, oyster mushroom is beneficial to boost the immune system of body. Fraction of $\beta$-glucan in this mushroom has potent antitumor activity in Ehrlich tumor and sarcoma 180 (Mowsumi \& Choudhary 2010, Facchini et al. 2014).

High plasma cholesterol can lead to atherosclerosis and can be fatal. Oyster mushrooms are ideal dietary substance for the prevention and treatment of hypercholesterolaemia due to high content of dietary fiber, sterol, proteins and microelements. P. ostreatus produces Lovastatin as secondary metabolite, which is responsible for its hypolipidemic effect as lovastatin reduces blood cholesterol level by inhibiting the HMG-Co A reductase enzyme. It also shows anti-apoptotic effect which is useful against several neurodegenerative problems and myocardial infarction resulting from excessive apoptosis (Hossain et al. 2003, Lakshmanan \& Radha 2013). Oyster mushrooms are 
very much rich in fiber. These fibers bind the cholesterols in gut, facilitate its fecal excretion from the body. Moreover, fibers form and increase the bulk of stool, speed bowel movement, decrease the discharge time and thus reduce the risk of colon cancer and other gastrointestinal tract related disturbances (Mowsumi \& Choudhary 2010).

\section{Polyporaceae}

Fomes fomentarius (L.) Fr., Summa veg. Scand., Sectio Post. (Stockholm): 321 (1849) Fig. 4

Pileus 60-210 mm broad, bracket to shell-shaped, becoming hoof-shaped, surface woody hard, smooth, zonate with different shades of gray to brown; margin obtuse, finely velutinate; context thick, tough, leathery, brownish. Pore surface white to gray, becoming brownish with age, rounded, 2-3 per mm; tubes up to $90 \mathrm{~mm}$ deep, concolorous with pore surface. Stipe absent. Taste and odour not recorded. Spore deposit not found.

Habit and habitat - Solitary to gregarious, growing on living and dead wood of Quercus sp.

Specimen examined - India, Uttarakhand, Rudraprayag, Chopta-Baniyakund, RPB/US/PU0678, 19, July 2015.

Medicinal properties - Fomes fomentarius (Tinder fungus) also called as "Mudi" in China, has been used as a traditional Chinese and Korean medicine for many centuries in treatment of various diseases such as gastroenteric disorder, hepatocirrhosis, oral ulcer, inflammation, and various cancers. Previous studies of this fungus have revealed its various appealing biological activities, including antidiabetic, anti-inflammatory, antioxidant and anticancer. Ethanol extract of F. fomentarius is very effective in inhibiting growth of Bacillus subtilis, Escherichia coli, Klebsiella pneumoniae and Pseudomonas aeruginosa (Chen et al. 2011, Kim et al. 2014).

Apoptosis (programmed cell death) plays an important role in the regulation of tissue development, differentiation and homeostasis in the immune system. Induction of apoptosis is a common mechanism of antitumor drugs (Amos et al. 1998, Ahmad et al. 2010). MFKF-AP1 $\beta$ is a polysaccharide present in F. fomentarius, and can be treated as an anticancer agent as it is reported to show a cell growth inhibitory effect on lung cancer cells by promoting apoptosis (Kim et al. 2014).

Trametes versicolor (L.) Lloyd, Mycol. Notes (Cincinnati) 65: 1045 (1921)

Figs $7 \& 8$

Pileus 30-85 mm broad, hemispherical, imbricate, often fused with other bracket, surface dry, tomemtose or velvety, variable in colour, concentric zones of various shades of brown to reddish; context yellowish white (2A2), leathery. Pore surface yellowish white (2A2) to grey, pore rounded to angular, 3-5 per mm, tough, fibrous, up to $4 \mathrm{~mm}$ thick, unchanged on bruising; tubes concolorous, up to $3 \mathrm{~mm}$ deep. Taste and odour indistinct. Spore deposit white.

Habit and habitat - Growing in clusters or rosettes on deadwood.

Specimen examined - India, Uttarakhand, Nainital, Bheemtal, RPB/US/PU-1408, 27 September 2016.

Medicinal properties - Trametes versicolor is a Chinese medicinal mushroom known to possess a wide range of biological activities. Its name is derived from the variously colored basidime. It is also known as "The Turkey tail mushroom" and called "Yun Zhi" in China (i.e., cloud-like mushroom), probably due to the fact that its wavy surface is covered with fluff (Chu et al. 2002, Cui \& Chisti 2003). More than 120 strains of T. versicolor are recorded in the Compendium of Chinese Materia Medica (Ng 1998).

The protein-bound polysaccharides of $T$. versicolor have been used as immunopotentiators and therapeutics for years. Therapeutic potential of this polypore is due to its bioactive polysaccharopeptides. The best known commercial polysaccharopeptide preparations of $T$. versicolor are polysaccharopeptide Krestin (PSK) and polysaccharopeptide PSP. Both products are obtained from the extraction of $T$. versicolor mycelia. PSK is approved for use in cancer treatment in Japan. Isolated in the 1960s, by 1987 over $25 \%$ of the Japanese expenditure on anticancer agents was spent on PSK (Sullivan et al. 2006, Mattos-Shipley et al. 2016). 
PSP and PSK have ability of immunopotentiation by inducing production of interleukin-6, interferons, immunoglobulin- G, macrophages, and T-lymphocytes; counter immunosuppressive effects of chemotherapy, radiotherapy, and blood transfusion; tumors; inhibition of proliferation of various cancers by inducing production of superoxide dismutase (SOD), glutathione peroxidase and improvement in appetite and liver functions (Cui \& Chisti 2003).

Extracts of $T$. versicolor have a broad spectrum of antibacterial and antifungal activities against common pathogens such as Escherichia coli, Pseudomonas aeruginosa, Staphylococus aureus, Candida albicans, Klebsiella pneumoniae, Listeria monocytogenes, and Streptococus pneumoniae. The antimicrobial effects of the extract are possibly due to the activation of polymorphonuclear cells and an increased secretion of antimicrobial cytokines (e.g., tumor necrosis factor, IL-1) (Chu et al. 2002).

\section{Russulaceae}

Lactarius deliciosus (L.) Gray, Nat. Arr. Brit. Pl. (London) 1: 624. (1821)

Fig. 9

Pileus 40-120 mm broad, convex when young, becoming planoconvex in age, with central depression; surface glabrous, dry, viscid when moist, distinctly zonate, light orange (6A4-6A5), orange (6A6-6A7) to deep orange (6A8), greyish green (27B4-27B5) on bruising; margin inrolled when young, plane at maturity; context up to $6 \mathrm{~mm}$ thick at disc, gradually thinning toward margin, centrally orange white (5A2), pale orange (5A3) toward surface, soon discolouring greyish green ((27B4-27B5). Lamellae close to crowded, adnate to subdecurrent, forking near stipe, pale orange (5A3) to light orange (5A4), turning greyish green (27B4-27B5) on bruising, lamellulae numerous. Stipe 40-85 × 5-17 mm, cylindrical, surface dry, concolorous with pileus, hollow. Latex orange (6A7), scarce. Taste mild to slightly acrid. Odour Pleasant, Fruity. Spore deposit yellowish white (3A2).

Habit and habitat - Solitary to gregarious, found to grow under Abies pindrow in temperate mixed forests.

Specimens examined - India, Uttarakhand, Rudraprayag, Chopta-Baniyakund, RPB/US/PU0611, 14 July 2015; Nainital, Mukteshwar, RPB/US/PU-1318, 16 August 2016.

Medicinal properties - Lactarius deliciosus (The saffron milk cap) is proven to show potent antimicrobial activities, particularly against Alternaria alternata, Aspergillus niger, Bacillus cereus, Bacillus subtilis, Candida albicans, Cladosporium cladosporioides, Escherichia coli, Fusarium oxysporum, Klebsiella pneumoniae, Mucor mucedo, Mycobacterium sp., Penicillium chrysogenum, Penicillium expansum, Proteus mirabilis, Pseudomonas aeruginosa, Staphylococus aureus and Trichoderma viridae (Dülger et al. 2002, Kosanić et al. 2016, Onbaşili et al. 2015).

Hou et al. (2013) purified a polysaccharide, LDG-A from the extract of $L$. deliciosus which exerted antitumor activity on mice transplanted S180 and significant tumour growth inhibition was detected in LDG-A treated mice. It also triggered the activation of immune responses as immune organs such as liver, spleen and thymus appeared to be firmer and more regular. Activated macrophages have remarkable role against tumor cells due to macrophage- mediated tumor cytotoxicity or antibody-dependent cellular cytotoxicity (ADCC) by releasing cytotoxic mediators (TNF- $\alpha$ and NO). LDG-A activated the release of TNF- $\alpha$ and NO of macrophages.

\section{Schizophyllaceae}

Schizophyllum commune Fr. [as 'Schizophyllus communis'], Observ. mycol. (Havniae) 1: 103 (1815)

Figs $2 \& 3$

Pileus 10-40 mm broad, fan-shaped bracket or irregular to shell-shaped, surface dry, white to greyish, covered with dense, tiny fibrils, fused at the base with other brackets; context thin, leathery, white to light grey. Hymenophore consisting of longitudinally split gill-like folds, distant, whitish to grey. Stipe absent. Taste and odour indistinct. Spore deposit white.

Habit and habitat - Solitary, gregarious to clustered, on dead or decaying wood. 
Specimen examined - India, Uttarakhand, Nainital, Bheemtal, RPB/US/PU-1407, 27 September 2016.

Medicinal properties - Schizophyllum commune is also known as split gill fungus, name derived from the gills which are longitudinally split and folded backward. It is a common edible fungus among Malayan community in Malaysia and also used as a nutritional food in south-east Asia (Han et al. 2005, Mirfat et al. 2014). Secondary metabolites of this fungus possess anticandida, anti-tumor and anti-viral properties (Ooi \& Liu 1999, Wasser 2002). Dichoromethane extracts of $S$. commune are highly effective as an anti-bacterial agent for gram positive as well as gram negative bacteria (Mirfat et al. 2014).

Antitumor, anticancer, antiviral and immunomodulating activities are also evident in $S$. commune due to presence of 'Schizophyllan', a $\beta$ 1-3, $\beta$ 1-6D-glucan (Kidd 2000, Rau et al. 1992). It also activates macrophages which results in augmentation of T-cell activities and increases sensitivity of cytotoxic LAK and NK cells to Il-2 (Rai et al. 2005). The degraded forms of Schizophyllan have anti-human immunodeficiency virus (HIV) activity (Muenzberg et al. 1995).

\section{Tremellaceae}

Tremella fuciformis Berk., Hooker’s Journal of Botany and Kew Garden Miscellany 8: 277 (1856)

Basidiomata up to $110 \times 70 \mathrm{~mm}$, gelatinous, translucent white to white, composed of thin, erect, branching fronds; surface smooth, shiny. Context gelatinous, transparent to whitish. Taste and Odour indistinct. Spore deposit not found.

Habit and habitat - Growing on the log of Quercus sp. in a moist temperate mixed forest.

Specimens examined - India, Uttarakhand, Chamoli, Mandal, RPB/US/PU-0712, 19 July 2015; Tehri, Dhanaulti, RPB/US/PU-0767, 31 July 2015; Uttarkashi, Purola, RPB/US/PU-0791, 01 August 2015.

Medicinal properties - Tremella fuciformis has been widely used in Chinese cuisines and known as a tonic for "weakness and ageing" Chinese herbal medicines. It possesses high dietary fiber content and significantly decreases serum triglycerol level. T. fuciformis polysaccharide (TFP), has good stability as well as excellent moisturizing and antiwrinkle effect. A carboxymethylated polysaccharide (CATP) derived from water-insoluble crude T. fuciformis polysaccharide showed moisture retention capacity and used in skin care (Wu et al. 2016).

SLTP (Sulfated low molecular weight polysaccharides) of $T$. fuciformis have free radical scavenging activity and can have considerable effects on cancer and Alzheimer's disease (Cheung 1996, Wu et al. 2007, Lai et al. 2010). Antioxidants of T. fuciformis can prevent neurodegenerative diseases by reducing the $\beta$-amyloid induced neurotoxicity on neuronal cells (Park et al. 2007). Glucans having a certain structure consisting of $\beta-(1 \rightarrow 3)$ - or $\beta-(1 \rightarrow 6)$ linked D-glucose residues have antitumor effects on Sarcoma 180 (Ukai et al. 1972). The polysaccharide fractions from fruit body of $T$. fuciformis display many physiological activities. It has the ability to induce human monocytes to produce interleukins (IL-1 and IL-6) and tumour necrosis factor in vitro (Gao et al. 1996a, b). Together with this immunomodulatory effect, the polysaccharide fraction composed of acidic and neutral heteroglycans has several pharmacological activities, such as hypoglycemic effect, anti-tumor activity and hypocholesterolemic activity (Park et al. 2007).

\section{Acknowledgements}

The authors are grateful to the Head, Department of Botany \& Microbiology, HNB Garhwal University, Srinagar Garhwal, for providing the necessary laboratory facilities during the course of present study and also thankful to Govind Ballabh Pant National Institute of Himalayan Environment and Sustainable Development (GBPNIHESD) Kosi-Katarmal, Almora for the financial assistance received to carry out this study. Mr. Tahir Mehmood and Mr. Aniket Ghosh (HNBGU) are duly acknowledged for their assistance in field. 


\section{References}

Ahmad A, Sakr WA, Rahman MWK. 2010 - Anticancer properties of indole compounds: mechanism of apoptosis induction and role in chemotherapy. Current Drugs Targets, 11, 652666.

Amos CL, Woetmann A, Nielsen M, Geisler C et al. 1998 - The role of Caspase 3 and Bclx $\mathrm{X}_{\mathrm{L}}$ in the action of Interleukin 7 (IL-7): A survival factor in activated human T cells. Cytokine, 10(9), 662-668.

Arora D. 1986 - Mushroom Demystified: A Comprehensive Guide to the Fleshy Fungi. Ten Speed Press, Berkeley, California.

Arora RK. 2015 - Cordyceps sinensis (berk.) Sacc.-an entomophagous medicinal fungus - a review. International Journal of Recent Advances in Multidisciplinary Research, 2(1), 01610170.

Bhandari AK, Negi JS, Bisht VK, Singh N, Sundriyal RC. 2012 - Cordyceps sinensis: fungus inhabiting the Himalayas and a source of income. Current Science, 103(8), 876.

Bishop KS, Kao CHJ, Xu Y, Glucina MP et al. 2015 - From 2000 years of Ganoderma lucidum to recent developments in nutraceuticals. Phytochemistry, 114, 56-65.

Bovi M, Carrizo ME, Capaldi S, Perduca M et al. 2011- Structure of a lectin with antitumoral properties in king bolete (Boletus edulis) mushrooms. Glycobiology, 21(8), 1000-1009.

Bovi M, Cenci L, Perduca M, Capaldi S et al. 2013 - BEL $\beta$-trefoil: A novel lectin with antineoplastic properties in king bolete (Boletus edulis) mushrooms. Glycobiology, 23, 578592.

Chakraborty S, Chowdhury S, Nandi G. 2014 - Review on Yarsagumba (Cordyceps sinensis) - An Exotic Medicinal Mushroom. International Journal of Pharmacognosy and Phytochemical Research, 6(2), 339- 346.

Champion HG, Seth SK. 1968 - A revised survey of forest types of India. Govt. of India publication, New Delhi 404 p.

Chang ST. 2004 - Mushrooms cultivation, nutritional value, medicinal effect, and environmental impact. CRC Press, Boca Raton, Fla, Boca Raton, Fla.

Chen W, Zhao Z, Li Y. 2011 - Simultaneous increase of mycelial biomass and intracellular polysaccharide from Fomes fomentarius and its biological function of gastric cancer intervention. Carbohydrate Polymers, 85, 369-375.

Cheung PCK 1996 - The hypocholesterolemic effect of two edible mushrooms: Auricularia auricula (Tree-Ear) and Tremella fuciformis (White Jelly-Leaf) in Hypercholesterolemic Rats. Nutrition Research 16(10), 1721-1725.

Chu KKW, Ho SSS, Chow AHL. 2002 - Coriolus versicolor: A Medicinal Mushroom with Promising Immunotherapeutic Values. Journal of Clinical Pharmacology, 42, 976-984.

Cui J, Chisti Y. 2003 - Polysaccharopeptides of Coriolus versicolor: physiological activity, uses, and production. Biotechnology Advances, 21, 109-122.

Das K, Sharma JR. 2005 - Russulaceae of Kumaon Himalaya. Botanical Survey of India. 255 pp.

De Silva DD, Rapior S, Fons F, Bahkali AH et al. 2012b - Medicinal mushrooms in supportive cancer therapies: an approach to anti-cancer effects and putative mechanisms of action. Fungal Diversity 55, 1-35.

De Silva DD, Rapior S, Kevin DH, Bahkali AH. 2012a - Medicinal mushrooms in prevention and control of diabetes mellitus. Fungal Diversity 56, 1-29.

De Silva DD, Rapior S, Sudarman E, Stadler M et al. 2013 - Bioactive metabolites from macrofungi: ethnopharmacology, biological activities and chemistry. Fungal Diversity 62, 140.

Dong Y, Jing T, Meng Q, Liu C et al. 2014 - Studies on the Antidiabetic Activities of Cordyceps militaris Extract in Diet Streptozotocin-Induced Diabetic Sprague-Dawley Rats. BioMed Research International 201, 1-11. 
Dülger B, Y1lmaz F, Gucin F. 2002 - Antimicrobial activity of some Lactarius species. Pharmaceutical Biology 40(4), 304-306.

Duncan CJ, Pugh N, Pasco DS, Ross SA. 2001 - Isolation of a galactomannan that enhances macrophage activation from the edible fungus Morchella esculenta. Journal of Agricultural and Food Chemistry 50, 5681-5685.

Facchini JM, Alves EP, Aguilera C, Gern RM et al. 2014 - Antitumor activity of Pleurotus ostreatus polysaccharide fractions on Ehrlich tumor and Sarcoma 180. International Journal of Biological Macromolecules 68, 72-77.

Gao Q, Jiang R, Chen H, Jensen E, Seljejid R. 1996a - Characterization and cytokine stimulating activities of heteroglycans from Tremella fuciformis. Planta Medica 62, 297-302.

Gao Q, Seljejid R, Chen H, Jiang R. 1996b - Characterisation of acidic heteroglycans from Tremella fuciformis Berk with cytokine stimulating activity. Carbohydrate Research 288, 135-142.

Gordan JD, Chay WY, Kelley RK, Ko AH et al. 2011 - And what other medications are you taking? Journal of Clinical Oncology 29, e288-e291.

Gray AM, Flatt PR. 1998 - Insulin-releasing and insulin-like activity of Agaricus campestris (mushroom). Journal of Endocrinology 157, 259-266.

Gurusamy R, Arthe R. 2012 - Effect of medicinal mushroom, Auricularia auricula-judae, polysaccharides against EAC cell lines. Research Journal of Biotechnology 7(2), 14-17.

Han CH, Liu QH, Ng TB, Wang HX. 2005 - A novel homodimeric lactose binding lectin from the edible split gill medicinal mushroom Schizophyllum commune. Biochemical and Biophysical Research Communication 336, 252-257.

Han ZH, Ye JM, Wang GF. 2013 - Evaluation of in vivo antioxidant activity of Hericiumerinaceus polysaccharides. International Journal of Biological Macromolecules 52, 66-71.

He X, Wang X, Fang J, Changa Y et al. 2017 - Structures, biological activities, and industrial applications of the polysaccharides from Hericium erinaceus (Lion’s Mane) mushroom: A review. International Journal of Biological Macromolecules 97, 228-237.

Heilmann-Clausen J, Verbeken A, Vesterholt J. 1998 - The Genus Lactarius. The Danish Mycological Society, Denmark, 287 pp.

Heleno SA, Stojkovic D, Barros L, Glamoclija J et al. 2013 - A comparative study of chemical composition, antioxidant and antimicrobial properties of Morchella esculenta (L.) Pers. from Portugal and Serbia. Food Research Internation 51(1), 236-243.

Hesler LR, Smith AH. 1979 - North American Species of Lactarius. The University of Michigan Press, Ann Arbor.

Holliday J, Cleaver M. 2004 - On the Trail of the Yak: Ancient Cordyceps in the modern world. www.mushworld.com/medicine.

Hossain S, Hashimoto M, Choudhury EK, Alam N et al. 2003 - Dietary mushroom (Pleurotus ostreatus) ameliorates atherogenic lipid in hypercholesterolaemic rats. Clinical and Experimental Pharmacology and Physiology 30, 470-475.

Hou Y, Ding X, Hou W, Song B et al. 2013 - Immunostimulant Activity of a Novel Polysaccharide Isolated from Lactarius deliciosus (L.) Fr. Indian Journal of Pharmaceutical Sciences 75(4), 393-399.

Jian JH, Slivova V, Valachovicova T, Harvey K et al. 2004 - Ganoderma lucidum inhibits proliferation and induces apoptosis in human prostatae cancer cells PC-3. International Journal of Oncology 24, 1093-1099.

Joshi S, Bhatt RP, Stephenson SL. 2012 - The current status of the family Russulaceae in the Uttarakhand Himalaya, India. Mycosphere 3(4), 486-501, Doi 10.5943 /mycosphere/3/4/12

Khamule R, Naksupan N, Ounaroon A, Saelim N. 2012 - Skin Wound Healing Promoting Effect of Polysaccharides Extracts from Tremella fuciformis and Auricularia auricula on the ex vivo Porcine Skin Wound Healing Model. $4^{\text {th }}$ International Conference on Chemical, Biological and Environmental Engineering IPCBEE vol.43 (2012) (C) (2012) IACSIT Press, Singapore DOI: 10.7763/IPCBEE. 2012. V43. 20 
Kharkwal P. 2016 - Ophiocordyceps sinensis and Pharmaceutical Industry. Research \& Reviews: Journal of Pharmacology and Toxicological Studies 4(4), 87-92.

Kibby G, Fatto R. 1990 - Keys to the Species of Russula in Northeastern North America. Kibby Fatto Enterprises, Somerville, New Jersey.

Kidd PM. 2000 - The use of mushroom glucans and proteoglycans in cancer treatment. Alternative Medicine Review 5 (1), 4-27.

Kim SH, Jakhar R, Kang SC. 2014 - Apoptotic properties of polysaccharide isolated from fruiting bodies of medicinal mushroom Fomes fomentarius in human lung carcinoma cell line. Saudi Journal of Biological Sciences 22, 484-490.

Kornerup A, Wanscher JH. 1978 - Methuen Handbook of Colour. $3^{\text {rd }}$ Ed. Eyre Methuen, London.

Kosanić M, Ranković B, Rančić A, Stanojković T. 2016 - Evaluation of metal concentration and antioxidant, antimicrobial, and anticancer potentials of two edible mushrooms Lactarius deliciosus and Macrolepiota procera. Journal of Food and Drug Analysis 24, 477-484.

Kumari P, Tewari LM. 2009 - Biodiversity in Uttrakhand Himalaya region. Nature and Science 7(3), 113-125.

Kuo YC, Lin CY, Tsai WJ, Wu CL et al. 1994 - Growth inhibitors against tumor cells in Cordyceps sinensis other than cordycepin and polysaccharides. Cancer Invest. 12, 611-615.

Lai PL, Naidu M, Sabaratnam V, Wong KH et al. 2013 - Neurotrophic properties of the Lion's mane medicinal mushroom, Hericium erinaceus (Higher Basidiomycetes) from Malaysia. International Journal of Medicinal Mushrooms 15, 539-554

Lai JX, He CF, Zhao J, Dong YM. 2010 - Optimization of extraction technology of polysaccharides from Tremella fuciformis on commercialized basis and its function in skin care cosmetics. China Surfactant Detergentÿ Cosmetic 40(4): 259-262.

Lakshmanan D, Radha KV. 2013 - Lovastatin production using Pleurotus ostreatus and its medicinal properties analysis by docking. African Journal of Pharmacy and Pharmacology 7(28), 1974-1986.

Lemieszek MK, Cardoso C, Nunes FHFM, Amorim de Barros AIRN et al. 2013 - Boletus edulis biologically active biopolymers induce cell cycle arrest in human colon adenocarcinoma cells. Food \& Function 4, 575-585.

Li, SP, Yang FQ, Tsim KWK. 2006 - Quality control of Cordyceps sinensis, a valued traditional Chinese medicine. Journal of Pharmaceutical and Biomedical Analysis 41, 1571-1584.

Liu C, Sun Y, Mao Q, Guo X et al. 2016 - Characteristics and Antitumor Activity of Morchella esculenta Polysaccharide Extracted by Pulsed Electric Field. International Journal of Molecular Sciences 17, 1-16.

Liu J, Shimizu K, Konishi F, Noda K et al. 2007 - Anti-androgenic activities of the triterpenoids fraction of Ganoderma lucidum. Food Chemistry 100, 1691-1696.

Mattos-Shipley KMJ, Ford KL, Alberti F, Banks AM et al. 2016 - The good, the bad and the tasty: The many roles of mushrooms. Studies in Mycology 85, 125-157.

Mau JL, Chang CN, Huang SJ, Chen CC. 2004 - Antioxidant properties of methanolic extracts from Grifola frondosa, Morchella esculenta and Termitomyces albuminosus mycelia. Food Chemistry 87, 111-118.

Mayell M. 2001 - Maitake Extracts and Their Therapeutic Potential - A Review. Alternative Medicine Review 6(1), 48-60.

Miller OK. 1981 - Mushrooms of North America. EP. Dutton, New York.

Miller RA. 2005 - Lab-grown. Cordyceps sinensis hybrid: A nano-processed Medicinal Mushroom that Really Delivers. Website: www.pharmaceuticalmushrooms.nwbotanicals.org.

Min BS, Nakamura N, Miyashiro H, Bae KW et al. 1998 - Triterpenes from the spores of Ganoderma lucidum and their inhibitory activity against HIV-1 protease. Chemical and Pharmaceutical Bulletin 46, 1607-1612.

Mirfat AHS, Noorlidah A, Vikineswary S. 2014 - Antimicrobial activities of split gill mushroom Schizophyllum commune Fr. American Journal of Research Communication 2(7), 113-124. 
Mizuno T. 1999 - Medicinal Effects and Utilization of Cordyceps (Fr.) Link (Ascomycetes) and Isaria Fr. (Mitosporic Fungi) Chineese Caterpiller Fungi, “Tochukaso” (Review). International Journal of Medicinal Mushrooms 1, 251-261.

Moller FH. 1950 - Part I. Danish Psalliota species. Preliminary Studies for a Monograph on the Danish Psalliotae. Friesia 4, 1-60.

Moller FH. 1952 - Part II. Danish Psalliota species. Preliminary studies for a Monograph on the Danish Psalliotae. Friesia 4, 135-217.

Money NP. 2016 - Are mushrooms medicinal? Fungal Biology 120, 449-453.

Mori K, Inatomi S, Ouchi K, Azumi Y et al. 2009 - Improving effects of the mushroom Yamabushitake (Hericium erinaceus) on mild cognitive impairment: a double-blind placebocontrolled clinical trial. Phytotherapy Research 23:367-372.

Mori K, Kikuchi H, Obara Y, Iwashita M et al. 2010 - Inhibitory effect of hericenone B from Hericium erinaceus on collagen-induced platelet aggregation. Phytomedicine 17, 1082-1085.

Mori K, Obara Y, Moriya T, Inatomi S et al. 2011 - Effects of Hericium erinaceus on amyloid $\beta$ (25-35) peptide-induced learning and memory deficits in mice. Phytotherapy Research 32, 67-72.

Moser M. 1978 - Keys to Agarics and Boleti (Polyporales, Boletales, Agaricales, Russulales). Gustav Fischer Verlag, Stuttgart.

Mowsumi FR, Choudhary MBK. 2010 - Oyster Mushroom: Biochemical and Medicinal Prospects. Bangladesh Journal of Medical Biochemistry 3(1), 23-28.

Muenzberg J, Rau U, Wagner F. 1995 - Investigations on the regioselective hydrolysis of a branched ß-1, 2-glucan. Carbohydrate Polymers 27, 271-276.

Nagai K, Chiba A, Nishino T, Kubota T et al. 2006 - Dilinoleoyl-phosphatidylethanolamine from Hericium erinaceus protects against ER stress-dependent Neuro2a cell death via protein kinase C pathway. Journal of Nutritional Biochemistry 17, 525-530.

Nahata A. 2013 - Ganoderma lucidum: A Potent Medicinal Mushroom with Numerous Health Benefits. Pharmaceutica Analytica Acta. 4, e159. doi: 10.4172/2153-2435.1000e159

Nanba H. 1997 - Maitake D-fraction: Healing and Preventive Potential for Cancer. Journal of Orthomolecular Medicine 12(1), 43-49.

Ng TB. 1998 - A review of research on the protein-bound polysaccharide (polysaccharopeptide, PSP) from the mushroom Coriolus versicolor (Basidiomycetes: Polyporaceae). General Pharmacology 30(1), 1-4.

Ng TB, Wang HX. 2005 - Pharmacological actions of Cordyceps, a prized folk medicine. Journal of Pharmacy and Pharmacology 57(12), 1509-1519.

Ngestiningsih D, Santoso, Rahayu RA. 2013 - Current management of overactive bladder: Insight from developing country. Basic Research Journal of Medicine and Clinical Sciences 2(6), $66-71$.

Nitha B, Meera CR, Janardhanan KK. 2007 - Anti-inflammatory and antitumour activities of cultured mycelium of morel mushroom, Morchella esculenta. Current Science 92(2), 235239.

Onbaşili D, Yuvali Çelik G, Katircioğlu H, Narin İ. 2015 - Antimicrobial, Antioxidant Activities and Chemical Composition of Lactarius deliciosus (L.) Fr. collected from Kastamonu Province of Turkey. Orman Fakültesi Dergisi 15(1), 98-103.

Ooi VEC, Liu F. 1999 - A review of pharmacological activities of mushroom polysaccharides. International Journal of Medicinal Mushrooms 1, 195-206.

Oyetayo V, Ariyo OO. 2013 - Antimicrobial and Antioxidant Properties of Pleurotus ostreatus (Jacq: Fries) Cultivated on Different Tropical Woody Substrates. Journal of Waste Conversion, Bioproducts \& Biotechnology 1 (2), 28-32.

Paliwal P, Barua D, Bharadia PD. 2015 - Cordyceps sinensis (Yarsagumba): A promising caterpillar mushroom. Journal of Harmonized Research in Pharmacy 4(4), 337-343. 
Pan K, Jiang Q, Liu G, Miao X et al. 2013 - Optimization extraction of Ganoderma lucidum polysaccharides and its immunity and antioxidant activities. International Journal of Biological Macromolecules 55, 301-306.

Papadopoulos I, Guo F, Lees S, Ridge M. 2007 - An exploration of the meanings and experiences of cancer of Chinese people living and working in London. European Journal of Cancer Care 16, 424-432.

Park HJ. 2014 - CARI III Inhibits Tumor Growth in a Melanoma-Bearing Mouse Model through Induction of G0/G1 Cell Cycle Arrest. Molecules 19, 14383-14395.

Park KJ, Lee SY, Kim HS, Yamazaki M et al. 2007 - The Neuroprotective and Neurotrophic Effects of Tremella fuciformis in PC12h Cells. Mycobiology 35(1), 11-15.

Patel KJ, Ingalhalli RS 2013 - Cordyceps militaris (L.: Fr.) Link - An Important Medicinal Mushroom. Journal of Pharmacognosy and Phytochemistry, 2(1), 315-319.

Phillips R. 1991 - Mushrooms of North America. Boston: Little Brown and Company.

Prasad P, Chauhan K, Kandari LS, Maikhuri RK et al. 2002 - Morchella esculenta (Guchhi). Need for scientific intervention for its cultivation in Central Himalaya. Current Science, 82(9), 1098-1100.

Rai M, Tidke G, Wasser SP. 2005 - Therapeutic Potential of Mushrooms. Natural Product Radiance 4(4), 246-257.

Rau U, Gura E, Olszewski E, Wagner F. 1992 - Enhanced glucan formation of filamentous fungiby effective mixing, oxygen limitation and fed-batch processing. Journal of Industrial Microbiology, 9, 19-26.

Reza Md A, Jo WS, Park SC. 2012 - Comparative Antitumor Activity of Jelly Ear Culinary Medicinal Mushroom, Auricularia auricula- judae (Bull.) J. Schrot. (Higher Basidiomycetes) Extracts Against Tumor Cells In Vitro. International Journal of Medicinal Mushrooms 14(4), 403-409.

Seth R, Haider SZ, Mohan M. 2014 - Pharmacology, phytochemistry and traditional uses of Cordyceps sinensis (Berk.) Sacc: A recent update for future prospects. Indian Journal of Traditional Knowledge, 13(3), 551-556.

Shiao MS. 2003 - Natural products of the medicinal fungus Ganoderma lucidum: occurrence, biological activities, and pharmacological functions. The Chemical Record 3, 172-180.

Singer R. 1986 - The Agaricales in Modern Taxonomy $4^{\text {th }}$ Ed. Bishan Singh Mahendra Pal Singh, Dehradun.

Sliva D. 2003 - Ganoderma lucidum (Reishi) in cancer treatment. Integr. Cancer Ther. 2, 358-364.

Son CG, Shin JW, Cho JH, Cho CK et al. 2006 - Macrophage activation and nitric oxide production by water soluble components of Hericium erinaceum. International Immunopharmacology 6(8), 1363-1369.

Stamets P. 1993 - Growing gourmet and medicinal mushrooms. Berkeley, CA: Ten Speed Press.

Sullivan R, Smith JE, Rowan NJ. 2006 - Medicinal mushrooms and cancer therapy: translating a traditional practice into Western medicine. Perspectives in Biology and Medicine 49, 159170.

Sun LX, Lin ZB, Li XJ, Li M et al. 2011 - Promoting effects of Ganoderma lucidum polysaccharides on B16F10 cells to activate lymphocytes. Basic and Clinical Pharmacology and Toxicology 108, 149-154.

Sun Y, Liu J. 2009 - Purification, structure and immunobiological activity of a water-soluble polysaccharide from the fruiting body of Pleurotus ostreatus. Bioresource Technology 100 (2), 983-986.

Tang W, Liu J, Zhao W, Wei D et al. 2006 - Ganoderic acid T from Ganoderma lucidum mycelia induces mitochondria mediated apoptosis in lung cancer cells. Life Sciences 80, 205-211.

Thongbai B, Rapior S, Hyde KD, Wittstein K et al. 2015 - Hericium erinaceus, an amazing medicinal mushroom. Mycological Progress 14, 1-23.

Trigg P, Gutteridge WE, Willaimson J. 1971 - The effect of cordycepin on malarial parasites. Transactions of the Royal Society of Tropical Medicine and Hygiene 65, 514-520. 
Ukai S, Hirose K, Kiho T, Hara C et al. 1972 - Antitumor activity on Sarcoma 180 of the Polysaccharides from Tremella fuciformis Berk. Chemical and Pharmaceutical Bulletin 20(10), 2293-2294.

Ukai S, Kiho T, Hara C, Morita M et al. 1983 - Polysaccharides in Fungi. XIII. ${ }^{1)}$ Antitumor Activity of Various Polysaccharides isolated from Dictyophora indusiata, Ganoderma japonicum, Cordyceps cicadae, Auricularia auricula-judae, and Auricularia Species. Chemical and Pharmaceutical Bulletin 31(2), 741-744.

Venkatachalapathi A, Paulsamy S. 2016 - Exploration of wild medicinal mushroom species in Walayar valley, the Southern Western Ghats of Coimbatore District Tamil Nadu. Mycosphere 7(2), 118-130, Doi 10.5943/mycosphere/7/2/3

Wachtel-Galor S, Yuen J, Buswell JA, Benzie IFF. 2011 - Ganoderma lucidum (Lingzhi or Reishi): A Medicinal Mushroom. Taylor and Francis Group.

Waheed I, Ahmad M, Rehman K, Rasool S. 2013 - Investigation of Haem Agglutination Activity in Agaricus campestris and Ballota limbata. International Journal of Advances in Pharmaceutical Research 5(1), 51-56.

Wang HX, Ng TB. 2006 - A laccase from the medicinal mushroom Ganoderma lucidum. Applied Microbiology and Biotechnology, 72, 508-513.

Wang J, Liu YM, Cao W, Yao KW et al. 2012 - Anti-inflammation and antioxidant effect of cordymin, a peptide purified from the medicinal mushroom Cordyceps sinensis, in middle cerebral artery occlusion-induced focal cerebral ischemia in rats. Metabolic Brain Disease 27, 159-165.

Wasser SP. 2002 - Review of medicinal mushrooms advances: good news from good allies. Herbal Gram 56, 28-33.

Wasser SP. 2011 - Current findings, future trends, and unsolved problems in studies of medicinal mushrooms. Applied Microbiology and Biotechnology 89, 1323-1332.

Wasser SP, Weis AL. 1999a - Medicinal properties of substances occurring in higher basidiomycetes mushrooms: current perspectives (review). International Journal of Medicinal Mushrooms, 1, 31-62.

Wasser SP, Weis AL. 1999b - Therapeutic effects of substances occurring in higher Basidiomycetes mushrooms: a modern perspective. Critical Reviews in Immunology 19, 6596.

Wong KH, Sabaratnam V, Abdullah N, Kuppusamy UR et al. 2009 - Effects of cultivation techniques and processing on antimicrobial and antioxidant activities of Hericium erinaceus (Bull.:Fr.) Pers. extracts. Food Technology and Biotechnology 47, 47-55.

Wu Q, Zheng C, Ning ZX, Yang B. 2007 - Modification of Low Molecular Weight Polysaccharides from Tremella fuciformis and their antioxidant activity in vitro. International Journal of Molecular Sciences 8, 670-679.

Wu S, Wang G, Yang R, Cui Y. 2016 - Anti-inflammatory effects of Boletus edulis polysaccharide on asthma pathology. American Journal of Translational Research 8(10), 4478-4489.

Wu Y, Choi M-H, Li J, Yang H, Shin HJ. 2016 - Mushroom Cosmetics: The Present and Future. Cosmetics, 3(3), 22; doi: 10.3390/cosmetics3030022.

Yang BK, Park JB, Song CH. 2002 - Hypolipidemic effect of exopolymer produced in submerged mycelial culture of five different mushrooms. Journal of Microbiology Biotechnology 12, 957-961.

Yang BK, Park JB, Song CH 2003 - Hypolipidemic effect of an Exobiopolymer produced from a submerged mycelial culture of Hericium erinaceus. Bioscience, Biotechnology, and Biochemistry, 67, 1292-1298.

Yang CH, Kao YH, Huang KS, Wang CY et al. 2012 - Cordyceps militaris and mycelia fermentation induced apoptosis and autophagy of human glioblastoma cells. Cell Death and Disease, 3, 1-9.

Ying J, Mao X, Ma Q, Zong Y et al. 1987 - Icones of medicinal fungi from China (translated, Yuehan X). Science Press, Beijing. 
Yoon SJ, Yu MA, Pyun YR, Hwang JK et al. 2003 - The nontoxic mushroom Auricularia auricula contains a polysaccharide with anticoagulant activity mediated by antithrombin. Thrombosis Research 112(3), 151-158.

Yuan Z, He P, Cui J, Takeuchi H. 1998 - Hypoglycemic Effect of Water-soluble Polysaccharide from Auricularia auricula-judae Quél. on Genetically Diabetic KK-A ${ }^{\mathrm{y}}$ Mice. Bioscience, Biotechnology and Biochemistry, 62(10), 1898-1903.

Yun TK. 1999 - Update from Asia. Asian studies on cancer chemoprevention. Annals of the New York Academy of Sciences 889,157-192.

Zhang JJ, Li Y, Zhou T, Xu DP et al. 2016 - Bioactivities and health benefits of mushrooms mainly from China. Molecules, 21, 938; doi: 10.3390/molecules21070938

Zhang XQ, Ip FC, Zhang DM, Chen LX et al. 2011 - Triterpenoids with neurotrophic activity from Ganoderma lucidum. Natural Product Research 25, 1607-1613.

Zheng S, Li C, Ng TB, Wang HX. 2007 - A lectin with mitogenic activity from the edible wild mushroom Boletus edulis. Process Biochemistry 42, 1620-1624.

Zhu JS, Halpern GM, Jones K. 1998 - The Scientific Rediscovery of an Ancient Chinese Herbal Medicine: Cordyceps sinensis Part I. The Journal of Alternative and Complementary Medicine, 4(3), 289-303. 